\title{
Islamic Antisemitism: Jews in the Qur'an, Reflections of European Antisemitism, Political Anti-Zionism: Common Codes and Differences
}

\section{Introduction}

Antisemitism in today's political and academic discourse very often is limited to discussions regarding the racial extreme right-wing antisemitism arising out of Christian anti-Judaism. This is only part of the story. The Jewish communities in Europe and the State of Israel are confronted with an antisemitism from three directions, however connected with each other: the extreme right, the extreme left, and political Islam. This essay focuses on Islamic antisemitism.

There is a discourse about the extent to which there is a connection between Islam as religion, political Islam, and anti-Jewish or antisemitic orientation. A closer look at the Qur'an is necessary to understand the complexity, even more so given that such old motifs are ignored and Islamic antisemitism is downplayed.

Other motifs, however, seem to be a result of the export of European antisemitism into the Middle East in colonial times and later, especially in the 1930s, as nationalist anti-British and anti-French sentiment developed. This development is called "Islamised Antisemitism."1 A good example and modern denier of a religious original Islamic antisemitism is Sadik J. al-Azm. He only considers Islamic antisemitism as "Islamised Antisemitism," as a reflection of Christian antisemitism and as a perception of the ideology of National Socialism in the 1930s. The answer is not an either or but a both and with respect to the source of antisemitic motifs and codes.

Since the founding of the Muslim Brotherhood by Hasan al-Banna ${ }^{2}$ and the further development under the influence of Sayyid Qutb ${ }^{3}$ and later Qaradawi, ${ }^{4}$

1 W. Benz, ed., Handbuch des Antisemitismus: Judenfeindschaft in Geschichte und Gegenwart, 3 vols. (Berlin: de Gruyter, 2008-2013), 3:133ff.

2 See A. Rahnema, ed., Pioneers of Islamic Revival (London: Zed Books, 2005).

3 See F. Hafez, Islamisch-politische Denker: Eine Einführung in islamisch-politische Ideengeschichte (Frankfurt: Peter Lang, 2015); he is not mentioning the antisemitic pamphlet of Qutb’s “Ma'rakatuna ma' a al-yahud-Our struggle with Jews” (Cairo: Dar al-Shuruq, 1989).

Ә OpenAccess. () 2020 Raimund Fastenbauer, published by De Gruyter. (cc) BY-NC-ND This work is licensed under the Creative Commons Attribution-NonCommercial-NoDerivatives 4.0 License. 
there is indeed a strong connection between Islamic anti-Jewish traditions in the Qur'an and European antisemitic ideas like the "Protocols of the Elders of Zion."

Moreover, the existence of Islamic antisemitism in the Arab world is often denied entirely, and its manifestations are explained as simple political polemic arising out of the conflict between Israel and the Palestinians. On the other hand, the policy of Israel has been equated with the policy of the Nazis, and there is talk about a Holocaust of the Palestinian people. Therefore, I want to take a closer look at the mentioned anti-Jewish traditions already in the Qur'an.

The Qur'an polemicizes against the Jews as does the New Testament but for other reasons than early Christianity, and in particular in its later Suras, after the Jewish tribes on the Arab peninsula did not join Mohammed and were defeated in battle conflicts. Two Jewish tribes were expelled from Medina, and the third, the Jewish tribe of Banu Kureiza in Medina, was completely destroyed and the surviving women enslaved.

Similar to the Gentile Christians who were disappointed about the majority of Jews refusing to join them, Mohammed and his followers experienced a similar disappointment, which resulted in anti-Jewish polemic. However, this polemic did not emerge from the accusation of killing of the son of god as it did with the Christians. Nevertheless, we can also find accusations of murder of the prophet.

The Hadith collection of al-Bukhari reports that Mohammed was lying in bed with a high temperature, claiming that a Jewish woman had given him poisoned lamb to eat. Similar to early Christianity and also to Martin Luther, we can separate two periods in the life of Mohammed regarding the relationship to the Jews: first, it was a positive one, but after the hopes for conversion had been disappointed, it became negative. Eventually, Islam also changed the direction of prayer from Jerusalem to Mecca. As it is the case with the New Testament, the Qur'an also includes Suras with positive content regarding the Jews, for example, Sura 5:20-21:

And when Musa (Moses) said to his people: “Oh, my people, remember Allah’s favour upon you when He appointed Prophets amongst you and made you kings, and granted to you what He had not granted to anyone else in the world. Oh, my people, enter the holy land which Allah has ordained for you; and do not turn back for then you will return as losers."

4 See Y. Al-Qaradawi, Approaching the Sunnah: Comprehension and Controversy, trans. J. Qureshi (London: International Institute of Islamic Thought, 2007). 
In Sura 109:6, it says: “To the 'Kafirin' [the unbelievers]: For you is your religion, and for me is my religion," in Sura 5:69, a similar sentiment is conveyed. These statements are contradicted by negative statements of a later date, after the armed conflicts with the Jewish tribes.

Sura 3:85 displays exactly the opposite of tolerance:

And whoever desires other than Islam as religion, it will never be accepted from him. And he, in the Hereafter, will be among the losers.

And Bukhari, in book two, Hadith 18, states the following:

Narrated Ibn 'Umar: Allah’s Messenger said: “I have been ordered (by Allah) to fight against the people until they testify that none has the right to be worshipped but Allah and that Muhammad is Allah's Messenger, and offer the prayers perfectly and give the obligatory charity, so if they perform that, then they save their lives and property from me except for Islamic laws and then their reckoning (accounts) will be done by Allah.”

This includes descriptions of Jews as those who "kill the prophets" (Sura 3:20-1), "Jews as cursed by Allah" (Sura 4:46), "Jews as descendants of apes and pigs" (Sura 2:65, 5:59-60, 7:166-8)-I will show some examples of this motif later on-"Jews as the worst enemies of the believers" (Sura 5:82), "the land of the Jews will belong to the Muslims" (Sura 33:27), "fight against them until they are humbled and will give the tribute" (Sura 9:29), and "they are the enemy, so be aware of them" (Sura 63:6). The religious relationship between Muslims and Jews that followed, alternated and was marked by highs and lows. Even in good periods, the Jews as people of a different faith were regarded, similar to the Christians, however, not as a group having equal rights. Instead they were tolerated "Dhimmis," who had to pay a special tax. Nevertheless, there have repeatedly been pogroms.

Today, there is often simple Holocaust denial, because Holocaust remembrance would legitimate the State of Israel. This is the case with the Palestinian Authority as well as with the Iran, where international conferences of Holocaust deniers take place. Islamism means using the Islamic tradition in the Qur'an and the Hadiths for the establishment of a social order that is based on these principles. Antisemitism is one of the constant factors of political Islam, Islamism, characterised by the following elements: only the divine right is applicable, unity of religion and politics, dichotomy of believers and unbelievers, more militant Jihad, and differentiation of the world into characters of the "House of Islam" and the "House of War."

The founding of the Muslim Brotherhood by Hassan al-Banna brought a revitalization of anti-Jewish ideas and a new interpretation of the term "Jihad" in 
the direction of "Holy war against the unbelievers." It includes also a glorification of the love of death. This Islamic Sunni theology, and subsequently also the Shiite theology, indicate a regression towards a theology of fighting similar to the initial period of Islam. Believing in the return of the lost twelfth imam as Mahdi is part of the eschatological visions of representatives of the regime of Iran.

At the same time, the profane Baath party has been founded, which came to power in Iraq and Syria, and which, however, emphasizes the priority of the "nation" over the "religion." Thus, it also represented Christians such as the founder Michel Aflaq. In Lebanon, the largely Christian Falange Party was founded. Both were influenced by the fascist parties of Europe. Robert Wistrich explains the "NS impregnated terminology" of the Arabian region as follows:

Its roots are lying in the various ideological-political alliances between the German Nazis, prominent Arab nationalists, Islamic fundamentalists, and European fascists between 1933 and $1945 .^{5}$

There is an Arab slogan that fits here: "Bala misyu, bala mister fi-l-sama Allah, wa'l-ard Hitler"-“No more Monsieur, no more Mister, God in Heaven, and on earth Hitler." 6

The antisemitism of the Muslim Brothers was further developed by Sayyid Qutb. Of great influence was his essay "Our battle with the Jews," which he wrote in 1950. In his opus "Milestones" from 1964, he connected European and Islamic antisemitism. He declared the "World Judaism" as being the main enemy. The Mufti of Jerusalem, Al-Husseini, was the most prominent representative of political Islam in Palestine. He became an ally of the Muslim Brothers. He combined sympathy for German National Socialism, Italian fascism, and antiBritish Arab nationalism:

5 R. Wistrich, Der antisemitische Wahn: Von Hitler bis zum Heiligen Krieg gegen Israel (Berlin: Edition Critic, 2015), 7. The original German reads: "Ihre Wurzeln hatte sie in den diversen ideologisch-politischen Allianzen zwischen den deutschen Nazis, prominenten arabischen Nationalisten, islamischen Fundamentalisten und europäischen Faschisten zwischen 1933 und 1945.” Translation by the author of this article.

6 R. Wistrich, A Lethal Obsession: Anti-Semitism from Antiquity to the Global Jihad (New York: Random House, 2010), 679.

7 Ma'alim fi al-Tariq, also Ma'alim fi'l-tareeq, or Milestones, first published in 1964, is a short book in which he lays out a plan and makes a call to action to re-create the Muslim world on strictly Qur'anic grounds, casting off what Qutb calls Jahiliyyah. 
The antisemitic passages of the Qur'an were combined with the antisemitic forms of battle of the Third Reich, and the hatred toward Jews was acted out as Jihad. ${ }^{8}$

The killing of Mohammed and the expulsion of the Jews from Medina is used as a good example for a religious legitimation of the killing. In 1943, al-Husseini said on the occasion of the anniversary of the Balfour Declaration:

Germany is also fighting against the common enemy, who was oppressing the Arabs and Mohammedans in their various countries. It recognized the Jews properly and decided to find a definite solution for the Jewish threat, which will settle the harm they are doing in the world. ${ }^{9}$

Bernard Lewis was one of the first Islamic scientists who at the beginning of the 1980s spoke for the first time of a "new" Islamic antisemitism in his book Semites and Antisemites. ${ }^{10}$ The described image of Israel and Palestine led to a rejection of peace talks. This was already indicated in the charter where the exclusive selfconception is outlined.

The Statute of the Palestinian organization of the Muslim Brothers, Hamas, reads as follows:

The Islamic resistance movement is a distinct Palestinian movement which owes its loyalty to Allah. It derives from Islam its way of life. And it strives to raise the banner of Allah over every inch of Palestine. ${ }^{11}$

8 M. Küntzel, Djihad und Judenhass: Über den neuen antijüdischen Krieg (Freiburg: Ça Ira, 2003), 9. See also S. Grigat, "Nicht konsequent bekämpft," interview by V. Dolna, Die FURCHE, February 5, 2015, https://www.furche.at/religion/nicht-konsequent-bekaempft-1192762.

9 A. Feuerherdt, "Der Mufti, die Deutschen und die Shoa," issued October 29, 2015, accessed November 26, 2019, https://lizaswelt.net/2015/10/29/der-mufti-die-deutschen-und-die-shoa/. The original German reads: "Auch Deutschland kämpft gegen den gemeinsamen Feind, der Araber und Mohammedaner in ihren jeweiligen Ländern unterdrückt. Es hat die Juden sehr klar als das erkannt, was sie sind und beschlossen, eine Endlösung für die jüdische Gefahr zu finden, die die Geißel der Welt, die die Juden sind, beseitigen wird." Translation by the author of the article.

10 See B. Lewis, Semites and Anti-Semites (New York: Norton, 1986).

11 Hamas, "The Charter of Allah: The Platform of the Islamic Resistance Movement (Hamas)," translated and annotated by R. Israeli (Jerusalem: The Hebrew University, Harry Truman Research Institute), article 6; Bundeszentrale für politische Bildung, "Antisemitismus und Antizionismus in der Charta der Hamas,” issued July 4, 2011, accessed January 2, 2016, https://www. bpb.de/politik/extremismus/islamismus/36358/antisemitismus-in-der-charta-der-hamas?p=all. 
In context of these views, you can also repeatedly find a call for "Jihad" in the text, whereby this is meant as a call for a violent battle. Thus, it says for example:

The Islamic resistance movement regards Nationalism as part and parcel of its religious faith. Nothing is stronger or deeper in Nationalism than an enemy who sets foot on the land of the Muslims and mistreats it. Thus, it becomes an individual duty binding on every Muslim man and woman to confront the enemy with Jihad. ${ }^{12}$

The above-mentioned views and quotations are by no means just anti-Zionist against Israel (compare with article 7, remark by the author of this article). They are clearly antisemitic and directed towards the Jews. The first indication appears already in the choice of words, since the text calls the hostile actors clearly not "Israelis" and almost never "Zionists." The expression "Jews" for the respective enemy is predominant.

The Deputy Minister for Religious foundations of Hamas, Abdallah Jabru, expressed this on February 28, 2010, with the following words:

Jews are like strange bacteria, they are microbes without precedent in this world. Allah shall destroy the dirty Jewish people, because they have no religion and no conscience! I condemn everyone who thinks that a normal relationship with Jews would be possible, everyone who sits together with Jews, everyone who thinks that Jews would be humans! Jews are not humans, they are no people. They have no religion, no conscience, no moral values! $!^{13}$

Moreover, it reads as follows: "By its Jewish character and Jewish citizens, Israel is provoking Islam and the Muslims.” Direct calls for use of violence in the text of the Hamas charter also reveal its antisemitic character:

The prophet [...] said: The time will come when Muslims will fight the Jews and kill them until the Jews hide behind rocks and trees, which will cry: O Muslim, o servant of Allah, there is a Jew hiding behind me, come and kill him! This will not apply to the Gharqad, which is a Jewish tree! ${ }^{14}$

12 Hamas, "The Charter of Allah."

13 "On Al-Aqsa TV, Hamas Deputy Minister of Religious Endowments Calls for Jews to be Annihilated, Saying They Are Bacteria, Not Human Beings; Following President Obama's Election, Said in Friday Sermon: We Must 'First Check if His Heart is Black or White'.” MEMRI, Special Dispatch no. 2858, issued March 15, 2010, https://www.memri.org/reports/al-aqsa-tv-hamasdeputy-minister-religious-endowments-calls-jews-be-annihilated-saying-they.

14 Hamas, "The Charter of Allah," article 7. 
Article 22 of the charter speaks about the Jews controlling the world media, and article 28 of the secret organizations of the Jews like Rotary, Lions, etc.

Apart from anti-Israeli polemics, it includes almost all antisemitic religious, political, and social stereotypes with regard to the Jews. Muslim representatives -also in Austria-try to create a different picture, the image of Muslim as a victim in Europe. Thus, Farid Hafez calls Islamophobia "a projection surface of tabooed anti-Semitism"15 in his comment. As counter-proof of Islamic antisemitism, he mentions that Mohammed had married a Jewish woman. He also takes a stand against representatives of the Euro-Islam, like Bassam Tibi.

In all of this, there is no mention of the fact that Safiyya bint Huyayy, the eleventh wife of the prophet, was a descendent from the Jewish Banu Nadir tribe, which suffered a crushing defeat by the prophet in which the men were killed and the women enslaved. This systematic belittlement can also be seen in a sermon of the Viennese imam Adnan Ibrahim in the Shura mosque in ViennaPraterstern:

\footnotetext{
Exactly as Sheikh al Gazali said: Allah said of the Jews: "We have cursed them and hardened their hearts: They distort the meaning of words from their right place.” They played with their religion, and who do you think did it? The scholars of the Jews. Do you think that someone of the crowd is able to do this? No. It has to be done by someone who is entrusted with the religion to the highest degree: the rabbis, the religious leaders, the scholars. They are the ones who manipulated the words of G'd and changed them. This is why they are cursed, because they violated the regulations of G'd and misused their religious duties. They broke the covenant with G'd. And it is not as some of you may think, that G'd is punishing such people immediately. No. But they have been cursed, their hearts hardened, so that they changed the words of G'd. ${ }^{16}$
}

Since the first Gulf war in 1990/91, we can notice a re-Islamization, especially in the second and third generations of Muslims in Europe. This is a development of a transnational religious identity as part of the Ummah, the community of all Muslims, and an identification with Muslim victims of the West or Russia (Bosnia, Chechenya, Afghanistan, Iran, Palestine). Israel is identified with the "perpetrators." With taking sides for Palestine, Muslims try to express their own victim role in Europe.

15 M. Sterkl, “Hafez: 'Der Islam ist in Europa schon lange keine Religion mehr', Der Standard, January 12, 2015, https://www.derstandard.at/story/2000010249228/hafez-der-islam-ist-in-euro pa-schon-lange-keine-religion.

16 I. Adnan, “The Signs of a False Muslim Preacher," April 8, 2013, video, 3:53, https://www. youtube.com/watch? $\mathrm{v}=\mathrm{sUvjUjaEedU,} \mathrm{starting} \mathrm{min.} \mathrm{1:20.}$ 
The contemporary Jihad propagandist Yusuf al-Qaradawi, who reaches millions of Muslims in the Orient and Europe every day by using TV channels and the internet, is thanking Hitler for the Holocaust. Due to his equation of antisemitism and Islamophobia on one hand, and for denying Muslim antisemitism on the other hand, some academics like Wolfgang Benz finds himself exposed to ever-stronger criticism for some time:

For a few years, Benz claims that the so called Islamophobia has similar dimensions as Antisemitism. Schroeder, director of the Research Association on the SED state at Freie Universität Berlin, told the 'Frankfurter Rundschau' [...] “This is practically absurd if you look at the recent protests against Israel and the Jews." ${ }^{17}$

At the same time after polemics by right-wing politicians in Europe against Muslim Immigrants a polemic around the term "Islamophobia" started.

The term "Islamophobia" was first used by Ayatollah Khomeini and applied against non-religious Muslims, especially unveiled women. In the European area, it was first used by the British anti-racist Runnymede Trust in 1994. The term should outline unfounded fears about Islam or Muslims. Political practice, however, uses it as an ideological battle cry to suppress criticism of Islam.

Firm rejection against equating Islamophobia with antisemitism, as Wolfgang Benz does, comes from Julius Schöps, who argues that Islamophobia lacks motifs such as ritual murder or a Jewish world conspiracy (which conversely do exist in Islamic antisemitism, remark by the author of this article).

Michael Ley polemicizes against equating antisemitism and anti-Islamism as follows:

An amazing amount of weak characters in Europe proclaim loud and clear [...] that an alarming anti-Semitism is prevalent in this place. And anti-Islamism would be the new an-

17 "Klaus Schroeder: Antisemitismus unter Moslems wird tabuisiert," Junge Freiheit, July 25, 2014, https://jungefreiheit.de/politik/deutschland/2014/klaus-schroeder-antisemitismus-untermoselms-wird-tabuisiert/. The original German reads: "Benz behauptet schon seit einigen Jahren, daß die so genannte Islamophobie eine ähnliche Dimension wie der Antisemitismus habe,” kritisierte der Leiter des Forschungsverbundes SED-Staat an der Freien Universität Berlin. Dies sei nach den jüngsten Protesten gegen Israel und die Juden geradezu 'absurd'." Translation by the author of this article. Cf. also K. Schroeder, "Ich sehe keine neue Qualität," interview by M. Decker, Kölner Stadt-Anzeiger, July 22, 2014, https://www.ksta.de/interview-ich-sehekeine-neue-qualitaet-3867994; M. Frischberg, "Das Konzept 'Islamophobie' als Abwehr westlicher Zumutungen: Zur Genese eines Kampfbegriffes,” in Feindaufklärung und Reeducation: Kritische Theorie gegen Postnazismus und Islamismus, ed. S. Grigat (Freiburg: Ça Ira, 2006), 155-72; J. Bunzl, and A. Senfft, eds., Zwischen Antisemitismus und Islamophobie: Vorurteile und Projektionen in Europa und Nahost (Hamburg: VSA-Verlag, 2008). 
tisemitism. As the Jews experienced the baseless insinuation of having plans of world supremacy, the same happens now to the Muslims. ${ }^{18}$

Subsequently, he tries to prove that this time, however, the "insinuation" is based on a situational analysis.

In March 2002, the EUMC, European Monitoring Centre on Racism and Xenophobia, carried out a study on antisemitism in the countries of the European Union, when the severity of the Muslim antisemitism came to light. However, publication was delayed for ten months, because it may promote "Islamophobia" in Europe.

In connection with current criticism on the discrimination of immigrants on the one hand and Muslim antisemitism on the other hand, we should take a closer look at the relationship between "antisemitism" and "Islamophobia." The often-used equation is not correct. There is a substantial difference in the fact that antisemitism has an "eliminatory character," meaning that it wants to destroy the Jewish people. Its reasons and history of development are much more complex than is the case with Islamophobia. These eliminatory ideas are also true for the Shiite Islam in Iran and its threat of destruction that is directed towards Israel. Islamophobia in Europe is a form of xenophobia that has been populistically stirred up by the extreme right wing. The same extreme right wing is, however, not fundamentally Islamophobic but particularly critical about the State of Israel.

The extreme right wing severely criticized the populist parties that have a critical view of the European Union, however, do support Israel:

\footnotetext{
Mister Strache, Mölzer, Kabas and Lasare as well as Madame Sabaditsch-Wolff (not Sabbatic) have been invited by a certain Mister Elias Cohen, ex-general and ex-Member of Knesset. There was talk of "sincere hospitality" and "active dialogue." It all sounds great, but why not meet with the enslaved Palestinians of the West Bank [...] And then they adopted a from a national point of view unspeakable "Declaration of Jerusalem," in which they pretend to be "in the frontline of the battle for the Western community of values," which means for the world order of Obama, Sarkosy, Merkel \& Co.! Islam has been stigmatized as a "totalitarian system" and thus displayed as the enemy image [...] and with the Islamophobic Madame Sabaditsch-Wolff, who was proving her own incompetence by unspeakable tirades against
}

18 M. Ley, Der Selbstmord des Abendlandes: Die Islamisierung Europas (Osnabrück: Hintergrund, 2015), 11. The original German reads: "Eine erstaunliche Anzahl der schwachen Charaktere in Europa behauptet lauthals [...] bei uns grassiere ein bedenklicher Antisemitismus. Und Antiislamismus sei der neue Antisemitismus. Wie einst den Juden grundlos Weltherrschaftspläne unterstellt wurden, so jetzt den Moslems.” Translation by the author of this article. 
Islam and Muslims [...] the pilgrimage to the Western Wall and Yad Vashem was perhaps the first kowtow with regard to an intended participation in the government? ${ }^{19}$

They have no problems with Muslims outside the German-speaking area, if applicable, there is even solidarity in antisemitism:

Criticism of the right wing and the extreme right wing may, however, not lead to the slightest belittlement of Antisemitism of certain Muslims and Arabs in Germany, Europe and the Middle East. This is not only about the fact that "Mein Kampf" is a bestseller [...] in Turkey and that there has been a historical close relationship between the Grand Mufti of Jerusalem [...] and the Nazis and the Holocaust. What matters here and now is that the green (colour of the Islamists, remark by the author of this article) Nazis are behaving the same way as the "bio-German" Nazis, they [...] are hunting pro-Israeli demonstrators, [...] are beating Jews. $^{20}$

Antisemitism of the Palestinians is not limited to the Islamist groups of Hamas. The President of the Palestinian Authority, Mahmoud Abbas, has written a thesis including typical secondary antisemitism by equating National Socialism with Zionism, and indicating the number of Jews that have been killed by the Nazis

19 Die Umwelt 1 (2011). See also Die AULA (April 2011 and July/August 2011: 29). The original German reads: "Die Herren Strache, Mölzer, Kabas und Lasar sowie Madame Sabaditsch-Wolff (nicht Sabbatisch) waren von einem gewissen Herrn Elias Cohen, Ex-General und Ex-Knesset-Abgeordneter, eingeladen worden. Man sprach von 'ehrlicher Gastfreundschaft' und einem 'aktiven Dialog.' Klingt alles wunderbar, doch warum traf man nicht die geknechteten Palästinenser im Westjordanland [...]. Und dann verabschiedete man die aus nationaler Sicht unsägliche 'Jerusalemer Erklärung' worin man 'an vordester Front des Kampfes für die westliche Wertegemeinschaft' zu stehen vorgibt, also für die Weltordnung der Obamas, Sarkosys, Merkels \& Co.! Der Islam wird als 'totalitäres System' gebrandmarkt und damit zum Feindbild gemacht [...] und mit der islamophoben Madame Sabaditsch-Wolff, diedurch unsägliche Tiraden gegen den Islam und Moslems ihre eigene Inkompetenz bewies [...]. War die Pilgerreise an die Klagemauer und nach Yad Vaschem vielleichtder erste Kotau in Hinblick auf die beabsichtigte Regierungsbeteiligung?” Translation by the author of this article.

20 C. Henri, “Grüne Nazis?-Antisemitische Pogromstimmung in Europa,” Jüdische Rundschau, August 7, 2014, http://alt.juedischerundschau.de/gruene-nazis-antisemitische-pogromstimmungeuropa/. The original German reads: "Die Kritik an Rechten und extremen Rechten darf aber nicht dazu führen, den Antisemitismus von manchen Muslimen und Arabern in Deutschland, Europa und dem Nahen Osten auch nur im Geringsten zu verharmlosen. Es geht nicht nur darum, dass "Mein Kampf" in der Türkei [...] ein Bestseller ist und dass es eine historische enge Beziehung des Großmufti von Jerusalem [...] zu den Nazis und zum Holocaust gab. [...] Es geht hier und heute darum, dass sich die grünen Nazis verhalten wie "biodeutsche" Nazis: sie [...] jagen pro-israelische Demonstranten, [...] schlagen Juden, [...].” Translation by the author of this article. 
with 890,000. Then, discourse about Islamophobia makes possible a victimisation of Muslim society endangering necessary criticism and self-criticism.

The magazine AULA, pointing out a statement of the Malaysian prime minister Mahatir Mohamad, who at a conference of Islamic states on October 17, 2003, spoke of a "Jewish world supremacy," is an interesting example for Islamic antisemitism and its absorption into extreme right-wing groups. ${ }^{21}$

The participants of the EU-summit, which was taking place at the same time, avoided a condemnation of Mahatir's remarks due to the instigation of French president Chirac.

The word "Jew" is generally an insult in Arab groups. Islamists as well as their opponents insult leaders for being of Jewish descent, as for example the Muslim Brothers did with the Egyptian president Sissi.

This defamation, however, has its tradition. Vice versa, the same has been said of the founder of the Muslim Brotherhood, Hasan al-Banna, and of ISIS leaders and al-Qa'ida related organizations. Using the word "Jew" as an insult in Europe has also become part of the colloquial language of young people of Arab origin. It is part of a "cultural code.” Teachers in Germany ignore this insult with certain resignation,

because they prefer to not interpret the insult "Jew" as anti-Semitic, but as an insult, that is to be understood completely detached from its historic context. ${ }^{22}$

In the Islamic world, pointing out that a political opponent might assumingly have a Jewish background is also used as a political weapon for defamation. Islamic antisemitism is often underestimated. One reason for this is that it is merely regarded as polemic in connection with the Israeli-Palestinian conflict as also mentioned. Another reason is that it appears often in Arab or Muslim media, and although their messages are transmitted to Europe via television and internet and are spread by preachers of hate in mosques, they remain unnoticed here, because in English programs or in interviews with Islamic politicians, they use a different vocabulary. On the other hand, when it comes to pointing out antise-

21 “Mahathir verteidigt Äußerungen über Juden,” Der Standard, October 18, 2003, https://www. derstandard.at/story/1453552/mahathir-verteidigt-aeusserungen-ueber-juden.

22 G. M. Hafner and E. Shapira, Israel ist an allem schuld: Warum der Judenstaat so gehasst wird (Cologne: Eichborn, 2015), 91, and P. Gessler, Der neue Antisemitismus: Hinter den Kulissen der Normalität (Freiburg: Herder, 2004). The original German reads: “[...] weil sie 'Jude’ als Schimpfwort lieber nicht antisemitisch deuten, sondern als Schimpfwort, das völlig losgelöst von seinem historischen Kontext zu verstehen sei.” Translation by the author of this article. 
mitic agitation, they question the correct translation. This corresponds to the religious principle of "taqqia” [fear, caution] as per Sura 3:28.

Views on the relationship between Judaism and Islam are controversial. The Moorish Spain is often presented as a perfect example for Jewish-Islamic coexistence-especially at a time of the medieval Christian persecution of the Jews and the crusades-whereby mentioning on the other hand, that even in such periods, Jews (and Christians) only had the status of a tolerated minority and were subject to special regulations is omitted.

The fact that an Islamic (in particular Arab) antisemitism exists, has also for a long time been kept in the dark by Israeli scientists. The well-known Israeli historian Harkabi, for example, ignored this phenomenon. ${ }^{23}$ On the one hand, this can be explained by the fact that the state of Israel has been founded precisely because of the wish to escape (European) antisemitism, and on the other hand, scientists, who are close to the left political spectrum, do not want to point out Islamic antisemitism out of fear that they would strengthen the right wing in Israel. Zionism brought no end of antisemitism.

I have in my work studied five motifs found in the media that will be discussed in the following:

1. An eye for an eye, a tooth for a tooth

2. Jews as animals

3. Jews and murder

4. Conspiracy: The Protocols of Zion

5. Jews and money

\section{An Eye for an Eye, a Tooth for a Tooth: An anti-Jewish Motif of Christian and European Origin}

The pure motif "an eye for an eye, a tooth for a tooth" can almost exclusively be found in the European area. If mentioned in the Islamic-Arab areas, then it might as well only be understood as a copy and paste echo of the European media polemic. In any case, using the motif "an eye for an eye, a tooth for a tooth" fits perfectly for the post-Nazi secondary antisemitism that strives for a reversion of guilt or at least a compensation of guilt. Thus, the secondary post-Nazi antisemitism is turning around the antisemitic motive of the murder of Jews into "an eye for an eye, a tooth for a tooth." With this form of relieving antisemitism,

23 See Y. Harkabi, Arab Attitudes to Israel (Jerusalem: Keter, 1972). 
it not only stands quasi pari, because the Jews are also murderers with regard to the Palestinians but even more than that: by relativizing the Holocaust, the Jews remain the only actual murderers.

Different from the European secondary post-Nazi antisemitism that searches for a release from the historic responsibility and attempts a reversal of perpetrator and victim, the Holocaust denial or relativization in the Islamic area serves to free Zionism from its foundation myth. In doing so, the Holocaust is regarded as a cause for the foundation of the State of Israel. It was because of the Holocaust that the international community gave Israel to the Jewish people-which leaves out the previous Zionist history-and the true victims of the Holocaust would be the Palestinians. Would there have been no Holocaust or would it only be an invention of the Zionists, the establishment of the State of Israel would have happened without justification.

In the areas of the Palestinian Authority, Hamas and Fatah especially insinuate that Zionists have taken part in the Holocaust or on the contrary brought the Holocaust on the Palestinian people. In a television program of the Palestinian Authority from March 25, 2004, the narrator says:

They (the Jews) are the ones who committed the Holocaust, their knives are cutting in length and width into our flesh [...] they opened ovens for baking human beings [...] and if an oven is not burning any more, they light a hundred more. Their hands are covered with the blood of our children.

In the official newspaper of the Palestinian Authority Al-Hayat Al-Jadida from April 18, 2015, you can read that the actual amount of the murdered people is not six million, as the Zionists claim, but only about one or two million. Furthermore, the Zionists have been working together with the Nazis to force the Jews to emigrate to Palestine. Hitler himself is glorified among others in one of the children's magazines.

Holocaust denial or relativization is especially manifest in Islamic schoolbooks, particularly in the areas of the Palestinian authorities.

\section{Jews as Animals: Apes, Pigs, etc.}

The examined second motif of "Jews as animals (i.e., descendant from apes and pigs)" can primarily be found in Muslim antisemitism today but also in earlier and Medieval Christianity. It is not reflected in the "new anti-Zionist antisemitism” in Europe but only in the Islamic antisemitism. 


\subsection{Origin of the Motif}

According to the Jewish religious teaching, pigs belong to the unclean animals. According to Lev 11:7 and Deut 14:8, they are excluded from the food that may be eaten. Under the Seleucid emperor Antiochus IV (175-164 B.C.E.), the people tried to force Jews to sacrifice pigs and eat them.

Already in 2 Pet 2:22, it says referring to Jewish Christians, who turned away from their new faith and back to Judaism: "They encountered the proverb: the dog is eating again what he spewed out; the pig, after defecating, wallows in its excrements." John Chrysostom used the reference to the pig with regard to the Jewish religious service in the synagogue.

In the Qur'an, we can find many sections that Islamist circles have used for antisemitic agitation against Jews, especially Sura 2:65, 5:59-60, referring to a violation of the Shabbat rules, as well as 7:166-168, where Jews are generally called "sons of apes and pigs" or "apes and pigs." Sura 5:59-60 mentions this as a punishment for ahl al-kitab (the people of the book, referring to Christians and Jews), because they do not adopt the true religious belief; the other two sections deal primarily with the punishment for violating Shabbat.

In a different section, in connection with the battle against the Jewish tribe of the Banu Qurayza, the prophet himself calls the Jews "brothers of apes." Theologically, there are two different opinions in Islam about the meaning of these Qur'an Suras:

There are two opinions among the Ulama in this regard: The first is that the Jews, whom Allah transformed and turned into pigs, remained in that state until they died, without producing descendants. The other opinion is that the Jews who turned into pigs multiplied and produced descendants, and their line continues to this day.

\subsection{History of the Motif}

The animal depiction "Judensau" only dates back to the Middle Ages and is a picture motif of anti-Jewish Christian art. Judaism was portrayed as a creature similar to pigs for the first time in Brandenburg in 1230. Subsequently, antisemitic insults in variations such as "Saujude" or "Judenschwein" developed apart from the term "Judensau." 


\section{Jews and Murder}

Another common motif is the killing motif, from ritual murder all the way to organ robbery. By being partly profaned, motifs from religious sources turn into accusations of organ robbery.

\subsection{Origin of the Motif}

In the history of the nations, the motif of the ritual murder legend is quite frequent and probably recalls the human sacrifices of the early period. It can be found as an accusation against the indigenous people in China, or as an accusation of the Romans against the Christians, and of the Christians against the Gnostics.

Abraham's sacrifice of his son Isaac, which God did not accept, shows, as did also the sacrifice ritual of animals in the Temple of Jerusalem, that people in Judaism had overcome human sacrifices. Christianity connects the motif of the sacrifice of Isaac to the self-sacrifice of Jesus on the cross.

\subsection{History of the Motif}

The accusation with reference to the Jews appears for the first time in ancient Rome in texts of the Greek-Egyptian poet Apion, who claimed that the Jews would sacrifice Greeks in their temple. This accusation became known through the reply statement of Josephus.

The Damascus affair of 1840-an accusation of ritual murder brought by a priest of a Christian Order against the Jews of Damascus, after a Father and his servant had been murdered-potently introduced the motif for the first time in the Arab world respectively, in the Ottoman Empire, and it reverberated to Europe. However, in the previous years, there had already been accusations of ritual murder in Beirut in 1824, in Antakya in 1826, and in Hame in 1829. In the years after 1840, there had been a series of further ritual murder legends in Syria.

Today, it is frequently found in the media of the Islamic world. It seems that the European Christian myth of the ritual murder had been transferred to the Middle East and had been absorbed there combined with the Passover story. A contemporary transmutation of the motif can also be found in the claim about organ theft with killed Palestinians, not only in fundamentalist groups like the Hamas, but also in the less religious Fatah and the Palestinian Authority. 


\section{Conspiracy, Protocols of the Elders of Zion, Jewish World Supremacy}

Another common motif is the historically not very old motif of the "Protocols of the elders of Zion" and of Jewish world supremacy.

\subsection{Origin of the Motif}

The "Protocols of the Elders of Zion" is an alleged conspiracy of the Jews. Leaders of the international Jewry supposedly met at the cemetery of Prague to cunningly prepare for reaching world supremacy. The novel Biarritz, published by Hermann Ottomar Friedrich Goedsche under the pseudonym "Sir John Retcliffe," served as a template. It included a chapter according to which the leaders of the twelve tribes meet at the Jewish cemetery of Prague every hundred years.

Historically, the Protocols are a forgery done by the Russian tsarist secret service and edited by Sergej Nilius. They were first published in 1903 by the antisemitic print media of Russia. The first non-Russian edition was published in 1919 by the publisher "Verband gegen die Überhebung des Judentums e.V." (Association against the arrogance of Jewry, later called "Deutsch-Völkischer Schutz- und Trutzbund"-German Nationalist Protection and Defiance Federation). In 1921, The Times in London was the first to detect that the Protocols were a forgery. This was also the result of a court case in Switzerland.

\subsection{History of the Motif}

After World War I, German-folkish circles disseminated the Protocols in the German language area, and the Nazi propaganda tool "Der Stürmer" frequently picked up the stereotype of a Jewish world conspiracy.

Adolf Hitler wrote on this topic in "Mein Kampf":

What many Jews might do unknowingly, is knowingly clarified here. And this is what matters. No matter in which Jewish mind these revelations are rooted, it is of crucial matter that they reveal with almost terrifying certainty the nature and the activity of the Jewish people.

Also after the Shoah, world conspiracy phantasies of a Jewish Lobby that is thus silencing its critics have been used in the political discourse, for example in the Möllemann affair. 
Since around 1925, after the first translation into Arabic, they often have been used as part of the anti-Jewish polemic to prove that with this conspiracy, the Jews strive for reaching world supremacy. Deeply rooted stereotypes of the Jews helped absorb the idea of the Protocols in Islamic societies. Even in the rather secular Turkey, the "Protocols" were published 97 times. Sixty different editions exist in the Arab world.

Conspiracy can already be found in the disputes between the prophet Mohammed and the Jews of Medina.

First, Mohammed was by treaty bound with the Jews of Medina, however, he broke the contract. But according to the Islamic tradition, the Jewish side caused the breach. Mohammed reported a vision with the angel Gabriel who warned him that the Jews from the Banu Nadhir tribe would conspire to strike him dead with a rock. In Sura 59, we read:

\footnotetext{
When Allah's Messenger immigrated to Al-Madinah, he concluded a contract with the Jews, which stated that he will not fight against them and they would not fight against him. They soon violated the treaty that they had made with Allah's messenger. This is why Allah sent them to torture. It can never be staved off and the destiny that He decided reached them. He can never be resisted. The Prophet forced them to leave and give up their strong fortifications of which the Moslems would have never thought that they would control them once. The Jews thought that their fortifications would keep them save from Allah's torture, but not a bit did they help them against Allah. Thus came what they did not expect from Allah to them, and Allah's Messenger forced them to leave Al-Madinah... "Leave my country and do not live with me. You have planned betrayal."
}

In consequence, the tribe was chased away from the city and the property was confiscated. Next, the Jewish tribe of the Banu Qurayza was combated and defeated, the men were killed and the women and children enslaved. A tradition exists also, according to which a Jewish woman tried to poison the prophet.

The motif of the conspiratorial Jews was also transferred into being the cause of the schism between the Sunnis and the Shiites.

Another root lies in the figure of the Dajjal, a fraudulent character of the Islamic eschatology that is believed to appear at the end of days similar to the "Antichrist." According to the tradition, he will ride on a white donkey, accompanied by 70,000 men from Isfahan. These men will come from Jewish circles.

Also the Nazi propaganda among the Moslems attempted this equation with the Jews.

Contemporary Islamist circles see the idea of the Dajjal in connection with freemasons, Zionism, the Rothschilds and globalization. 


\section{Jews and Money (from Judas to Rothschild, ATTAC and Occupy Wall Street)}

\subsection{Origin of the Motif}

In the New Testament, Judas Iscariot is one of the twelve disciples of Jesus. According to Mark 3:19, with his betrayal he helped to capture Jesus, and in return he received thirty pieces of silver (Matt 26:15) from the high priest.

Based on the negative characterizations by Tertullian and Origen, the character of Judas has since the Middle Ages become a popular object of hatred in antisemitic passion plays. And the racial antisemitism of the Nazis picked up the Judas motif on the basis of Luther's characterization of Judas.

He became the prototype of the Jew greedy for money. This image was solidified after the Fourth Lateran council in 1215 with the Jews specializing in moneylending-since the Jews had no access to the Christian guilds, and since it was out of religious reasons forbidden for Christians to take interest from Christians (and for Jews when it came to Jews).

The motif finds its continuation in Shylock, which is the name of the Jewish usurer in Shakespeare's play The Merchant of Venice. Shylock represented usury and hatred towards Christians. Such characterizations existed before, including Christopher Marlow's play “The Jew of Malta” from 1591. At the time when The Merchant of Venice was written, there were no Jews in England.

\subsection{History of the Motif}

Rothschild is the name of a family of Jewish bankers from Frankfurt. The founder Mayer Amschel Rothschild was born in 1744. His son Nathan Mayer Rothschild immigrated to England in 1799. In the nineteenth century, the focus of the business was on international bond business, and a company group with five autonomous branches was established. From the onset of their influence on Europe's economic life, the Rothschilds were targets for partly antisemitic attacks.

\section{Summary}

The fact that the "New anti-Zionist antisemitism" is concentrated especially in Western Europe, can also be explained by the fact that-after nationalism has driven Europe into two World Wars and the Holocaust, and after the emergence 
of nation states in Europe such as Germany, Italy, or the Slavic states in Eastern Europe-it was a united Europe, in which the states of Europe saw the possibility of overcoming nationalism arising from national states. ${ }^{24}$

Thus, they are critical of political Zionism, which is seen as a delayed Jewish national movement. National ideas are only accepted in Third World countries and the Arab world, often because of a bad conscience regarding the colonial times. Since the Jews have been part of Europe's history, they are measured by "European standards," which again gives reason to point out the applied "double standards" and secondary antisemitism. The commemoration of the Shoah mingles with anti-Zionist criticism of Israel.

Several anti-Jewish motifs of Christian or European origin were-after experiencing a parallel development-reinforced in Islamist antisemitism (such as "Jews and murder/conspiracy" and "Jews and money." Thus, Islamic antisemitism reinforces a European motif, which was initially used in Christian antisemitism and later in racial antisemitism and connects it with the conspiracy motive that also exists in Islam.

The motif of connecting Jews with animals is basically only part of Islamic antisemitism. When it comes to "New anti-Zionist antisemitism," the motifs are open or in a coded way combined with leftist antisemitism and anti-imperialist criticism of capitalism, which is especially visible in the money motif as social criticism of "financial capital," compounded by the post-Nazi secondary antisemitism with its motive of "an eye for an eye" and the "reversal or equation of perpetrator and victim" with reference to Israel.

The "New anti-Zionist antisemitism" thus includes partly open, partly coded antisemitic motifs often of religious origin, which date back a long time, such as an eye for an eye, conspiracy, and blood libel, and which are often underestimated in the research on antisemitism. This work is meant as a contribution for a correct assessment.

Raimund Fastenbauer completed his studies in Political Science, Jewish Studies and Economics and was Secretary General of the Jewish Community of Austria from 2006-2019 with a special focus on the fight against antisemitism. He is an active member of the Documentation Centre of the Austrian Resistance, the Mauthausen Committee and Vice President of Bnai Brith Austria.

24 Cf. B. Tibi, "Migration aus der Welt des Islam und die Wiedereinführung von Judenhass und Antisemitismus nach Europa," in Die Zukunft Europas und das Judentum: Impulse zu einem gesellschaftlichen Diskurs, ed. O. Deutsch (Wien: Böhlau, 2017), 163-84. 


\section{Bibliography}

\section{Primary Sources}

Hamas. "The Charter of Allah: The Platform of the Islamic Resistance Movement (Hamas)." Translated and annotated by Raphael Israeli. Jerusalem: The Hebrew University, Harry Truman Research Institute.

Ibrahim, Adnan. "The Signs of a False Muslim Preacher.” April 8, 2013. Video, 3:53. https://www.youtube.com/watch?v=sUvjUjaEedU.

Qutb, Sayyid. "Ma'rakatuna ma' a al-yahud-Our struggle with Jews.” Cairo: Dar al-Shuruq, 1989.

\section{Secondary Sources}

Benz, Wolfgang, ed. Handbuch des Antisemitismus: Judenfeindschaft in Geschichte und Gegenwart. 3 vols. Berlin: de Gruyter, 2008-2013.

Bundeszentrale für politische Bildung. "Antisemitismus und Antizionismus in der Charta der Hamas.” Issued July 4, 2011. https://www.bpb.de/politik/extremismus/islamismus/ 36358/antisemitismus-in-der-charta-der-hamas?p=all.

Bunzl, John, and Alexandra Senfft, eds. Zwischen Antisemitismus und Islamophobie. Hamburg: VSA-Verlag, 2008.

Feuerherdt, Alex. "Der Mufti, die Deutschen und die Shoa." Issued October 29, 2015. Accessed November 26, 2019. https://izaswelt.net/2015/10/29/der-mufti-die-deutschenund-die-shoa/.

Frischberg, Manuel. "Das Konzept 'Islamophobie' als Abwehr westlicher Zumutungen: Zur Genese eines Kampfbegriffes." In Feindaufklärung und Reeducation: Kritische Theorie gegen Postnazismus und Islamismus, edited by Stephan Grigat, 155-72. Freiburg: Ça Ira, 2006.

Gessler, Philipp. Der neue Antisemitismus: Hinter den Kulissen der Normalität. Freiburg: Herder, 2004.

Grigat, Stephan. "Nicht konsequent bekämpft." Interview by Verena Dolna. Die FURCHE. February 5, 2015. https://www.furche.at/religion/nicht-konsequent-bekaempft-1192762.

Hafez, Farid. Islamisch-politische Denker: Eine Einführung in islamisch-politische Ideengeschichte. Frankfurt/Main: Peter Lang, 2015.

Hafner, Georg M., and Esther Shapira. Israel ist an allem schuld: Warum der Judenstaat so gehasst wird. Cologne: Eichborn, 2015.

Harkabi, Yehoshafat. Arab Attitudes to Israel. Jerusalem: Keter, 1972.

Henri, Clemens. "Grüne Nazis?-Antisemitische Pogromstimmung in Europa." Jüdische Rundschau, August 7, 2014. http://alt.juedischerundschau.de/gruene-nazis-anti semitische-pogromstimmung-europa/.

Küntzel, Matthias. Djihad und Judenhass: Über den neuen antijüdischen Krieg. Freiburg: Ça Ira, 2003.

Lewis, Bernard. Semites and Anti-Semites. New York: Norton, 1986. 
Ley, Michael. Der Selbstmord des Abendlandes: Die Islamisierung Europas. Osnabrück: Hintergrund, 2015.

N. N. "On Al-Aqsa TV, Hamas Deputy Minister of Religious Endowments Calls for Jews to be Annihilated, Saying They Are Bacteria, Not Human Beings; Following President Obama's Election, Said in Friday Sermon: We Must 'First Check if His Heart is Black or White'." MEMRI, Special Dispatch no. 2858. Issued March 15, 2010. https://www.memri.org/re ports/al-aqsa-tv-hamas-deputy-minister-religious-endowments-calls-jews-be-annihilatedsaying-they.

N. N. "Klaus Schroeder: Antisemitismus unter Moslems wird tabuisiert." Junge Freiheit, July 25, 2014. https://jungefreiheit.de/politik/deutschland/2014/klaus-schroeder-anti semitismus-unter-moselms-wird-tabuisiert/.

N. N. “Mahathir verteidigt Äußerungen über Juden.” Der Standard, October 18, 2003. https:// www.derstandard.at/story/1453552/mahathir-verteidigt-aeusserungen-ueber-juden.

Al-Qaradawi, Yusuf. Approaching the Sunnah: Comprehension and Controversy. Translated by Jamil Qureshi. London: International Institute of Islamic Thought, 2007.

Rahnema, Ali, ed. Pioneers of Islamic Revival. London: Zed Books, 2005.

Schroeder, Klaus. "Ich sehe keine neue Qualität.” Interview by Markus Decker. Kölner Stadt-Anzeiger, July 22, 2014. https://www.ksta.de/interview-ich-sehe-keine-neue-qual itaet-3867994.

Sterkl, Maria. “Hafez: 'Der Islam ist in Europa schon lange keine Religion mehr'." Der Standard, January 12, 2015. https://www.derstandard.at/story/2000010249228/hafezder-islam-ist-in-europa-schon-lange-keine-religion.

Tibi, Bassam. "Migration aus der Welt des Islam und die Wiedereinführung von Judenhass und Antisemitismus nach Europa." In Die Zukunft Europas und das Judentum: Impulse zu einem gesellschaftlichen Diskurs, edited by Oskar Deutsch, 163-84. Wien: Böhlau, 2017.

Wistrich, Robert. Der antisemitische Wahn: Von Hitler bis zum Heiligen Krieg gegen Israel. Berlin: Edition Critic, 2015.

Wistrich, Robert. A Lethal Obsession: Anti-Semitism from Antiquity to the Global Jihad. New York: Random House, 2010. 
